\title{
RELATIONSHIP BETWEEN GEOLOGIC PARENT MATERIAL AND GROWTH OF FOREST TREES IN THE GÖLHISAR BASIN IN SW ANATOLIA, TURKEY
}

\author{
AltunBas, S. $^{1 *}-{\text { AtAlAy, } \text { I. }^{2}-\text { SiLER, }}{ }^{3}{ }^{3}$ \\ ${ }^{I}$ Deprtment of Soil Science and Plant Nutriment, Akdeniz University, Antalya, Turkey \\ ${ }^{2}$ Department of Geography, Karabük University, Karabük, Turkey \\ ${ }^{3}$ Department of Geography, Firat University, Elazlğ, Turkey \\ *Corresponding author \\ e-mail:saltunbas@akdeniz.edu.tr \\ (Received $3^{\text {rd }}$ Apr 2019; accepted $20^{\text {th }}$ Aug 2019)
}

\begin{abstract}
Gölhisar Basin which is located in the southern part of Lakes Region, in SW of Turkey contains four main geologic parent materials composed of serpentine-peridotite, Mesozoic limestone, Neogene marl deposit and Quaternary colluvial deposit on which Calabrian pine (Pinus brutia) and Anatolian black pine (Pinus nigra subsp. pallasiana) grow. Tree productivity and/or growth rate is considerably different on these parent materials. This is mainly related to the weathering degree of serpentine-peridotite, stratification and compactness of marl deposit and the crack structure of limestone. For example, the productive Calabrian pine (Pinus brutia) trees grow on the deeply weathered serpentineperidotite parent material in the Gölhisar basin. Draft appearances of Calabrian pines are found on exposed peridotite-serpentine in sloping areas. Besides, tree biomass is low on compact marl deposit due to the fact that taproot development of trees is mostly prevented by the compact marl deposit and horizontal marl layers. The productivity of Calabrian pine and black pine (Pinus brutia) trees on the limestone is higher than on the marl deposit and low weathered serpentine in the study area, in general. The aim of this study is to illustrate the importance of parent materials containing serpentine-peridotite, limestone, marl and colluvial deposits on the growth of Pinus brutia and Pinus nigra trees in the Gölhisar Basin.
\end{abstract}

Keywords: tree growth, serpentine weathering, biome classification

\section{Introduction}

Forest trees mostly grow on exposed parent materials occurring most of sloping areas. Here the chemical and physical composition of the parent materials and their weathering degrees play very important roles in the growth of trees. Especially the weathering of the parent materials mostly contributes to the release of the plant nutrients and weathered parent materials form a soft ground to develop of the plant root system, in general. For this reason, there is close relationship between the weathering degree of the parent materials and biomass of trees and/or tree growth rate. According to studies carried out relating to the importance of the tree biomass in Turkey, the good/high site index (site quality class) stands and trees occur on the deeply weathered parent materials; whereas, the poor stands are found on the semi weathered and low weathered parent materials. For example, good site index black pine forests were established on the deep weathered serpentine in the Karsanti locality in east of Mediterranean Taurus Mountains, Dirgine locality and Yenice Basin in NW of Anatolia; while, poor site index forests appear on the low weathered and unweathered serpentine in the Datça Peninsula, Kemer locality, west of Antalya Gulf (Atalay and Efe, (2010a), (2014); Atalay, (2016a). 
In serpentine area of Kemer locality, CEC of soil in the poor stand is $8-10 \mathrm{cmol}_{\mathrm{c}} \mathrm{kg}^{-1}$, while this figure is about $38 \mathrm{cmol}_{\mathrm{c}} \mathrm{kg}^{-1}$ in good stand (Atalay, 2014). According to the study made on the parent material and biomass of the forest trees in the western part of Mediterranean Region, the highest productive forests are found on cracked limestone, the lowest one exists on the bare land of serpentine (Tetik and Yeşilkaya, 1997). It can be said that unweathered serpentine in the various parts of Anatolia is generally seen as bare land notably on the sloping area. Herbaceous plants only grow on the stabilized slopes on serpentine with thin soil cover.

On the other hand, different vegetation communities were established on the driftderived soil and bedrock-derived soil in Keen of Hamar in the Shetland (Carter, 1987). In the study to be made in Central Coastal range of California showed that plant available $\mathrm{Mg}$ and $\mathrm{Ca}$ in serpentine soils exceed values assessed in chert soils. Magnesium is nearly 3 times more abundant than $\mathrm{Ca}$ in the serpentine soils and ion uptake discrimination and ion suppression in the roots are major mechanisms for serpentine vegetation to tolerate the chemistry of serpentine soils (Oze et al., 2008). The vegetation of serpentines presents a wide range of appearances. Biologists have concentrated on the situations where serpentine vegetation is in sharp contrast with that of the surroundings (Proctor et al., 1975). Serpentine soils are extreme habitats for plants. These extreme habitat conditions are rich with floristic diversity, especially endemic and rare taxa. The species which are specialist for serpentine habitats can survive by developing adaptations toward these intense stress conditions (Going et al., 2009). The ecology of serpentine systems has a significant importance for the sustainability of biodiversity and preservation of species (Özdeniz et al., 2017).

As to limestone, cracked limestone having high content of clay on the sloping area contributes a good habitat for the growth of forest trees due to the fact that three roots easily develop toward the deep parts along the cracks of limestone. On the other hand, especially red Mediterranean soil (Alfisol/Luvisol) with clayey in texture and its CEC more than $40 \mathrm{cmol}_{\mathrm{c}} \mathrm{kg}^{-1}$ that developed along the thin cracks and voids and among the bedding surface of limestones also form suitable conditions for the growth of cedar (Cedrus libani), black pine (Pinus nigra) and Taurus fir (Abies cilicica) trees in the Taurus Mountains (Atalay, 1987, 1997, 2014; Atalay and Efe, 2014).

The stratification situation, particularly the inclination of the layer and compactness of marl deposits forms different environments in terms of the tree growth. Namely, good site index of forests are found on soft marl deposits, while poor site index stand occurs on the compact and horizontal layered marl deposit because tree root development is considerably prevented by compact and horizontal layers (Atalay and Efe, 2014; Gregorich et al., 2001). Vertical cracks and thin soft zone in the marl deposit support taproot development of tree roots in the marl deposit. For this reason, the high growth rate trees and forests are commonly seen in these areas. Marl deposit on the sloping areas is very vulnerable for erosion and sensitive land degradation (Cerda, 1999; Atalay et al., 2019a).

Deep weathered gneiss and micaschist producing sandy soil supports to grow of productive forest; while outcropped gneiss and micaschist appearing as a rocky land on the steep slope is generally absent from the forest. Volcanic sand and tuff deposit, and thick sandy soil developed on the granite and gneiss create a good habitat for the growth scots pine (Pinus sylvestris) under cold and subhumid climate and stone pine (Pinus pinea) in the Mediterranean climate in Anatolia (Atalay, 2014, 2016b). 
The importance of parent materials on the growth of plants is briefly mentioned some textbooks (Cunningham and Saigo, 1999; Foth, 1990; Smith and Smith, 2003).

The select of Gölhisar Basin as study area is related to display different parent material properties and forests. In this study our aim is to elucidate of the parent material effects on the three growths in the Gölhisar Basin which is located in the Lakes Region of SW Anatolia in Turkey (Fig. 1).

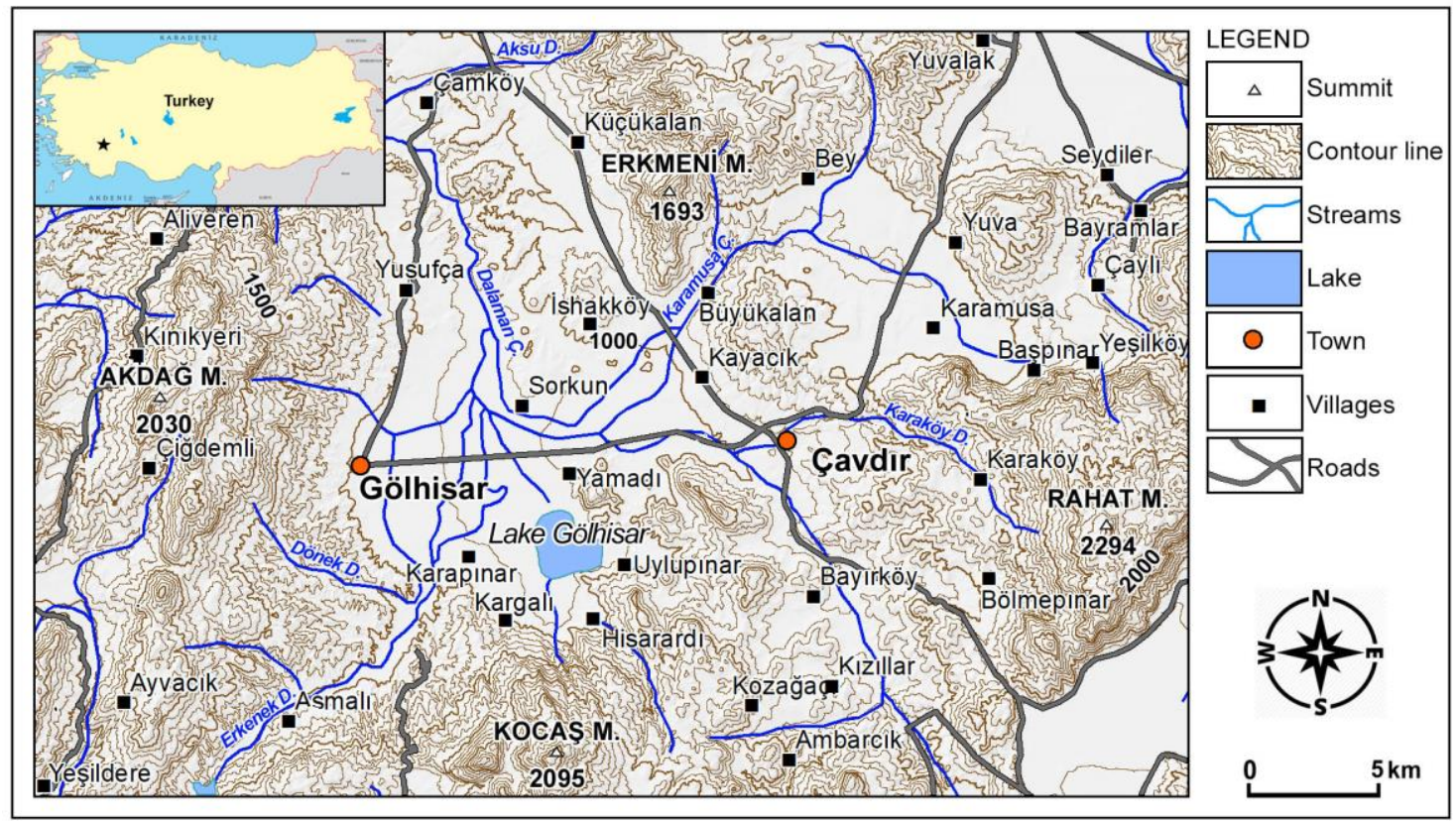

Figure 1. Location and topographic map of the study area

\section{Materials and methods}

General physical properties like the formation of geologic parent materials, topographic traits, climate, soil and vegetation, notably forest belts of the study area were briefly mentioned. The existence of different parent material and various forest clusters were taken into consideration in the selected experimental sites. Generally, in the selected experimental sites forest cluster and individual tree occurrence change sharply depending on parent material spreading. These areas are clearly seen in the sloping areas of Gölhisar Basin, because they have many parent materials composed of peridotite-serpentine, limestone, marl and colluvial deposit, and two main forest vegetation belts composed of Calabrian pine (Pinus brutia) and Anatolian black pine (Pinus nigra subsp. pallasiana). On the other hand, the main aim of the study is to reveal the growth rate of Pinus brutia and Pinus nigra on the different parent materials especially serpentine, limestone and marl deposit in the selected sites. Measurements of trees and collecting parent materials and soil samples were carried out in the summer season of 2018 in the study area (Figs. 1 and 2).

Pinus brutia experimental sites were selected on the different weathered serpentineperidotite, limestone; horizontal and inclined layers of marl deposit and colluvial deposit; Pinus nigra experiment sites were selected on serpentine and limestone in the Gölhisar Basin. In the selection of trees in the experimental sites the different weathering stages of parent materials were taken into consideration. The figures and 
graphs of trees showing the relationships among the age, diameter and height, and the parent material properties were prepared. Thus, the relationship between weathering situation of parent materials and the tree growth in the selected experimental sites was assessed. Relationship between tree growth and cation exchange capacity of the parent materials mainly indicating the weathering stages and plant nutriment capacity was explained. Special attendance was focused on significance of serpentine weathering on the vegetation growth and relating examples with serpentine were given not only experimental sites but also other places of the study area. Besides water allocation and surface erosion observations were made to explain the relationship between water and weathering properties of parent materials in the field. According to archaeological and historical knowledge human impact on the destruction of vegetation especially forest cover and its effect on the tree growth was mentioned. Lastly, statistical evaluation between tree growth and parent material was made.

On the other hand, to show the distribution of the forest trees and geologic parent material a profile and geologic parent material map were drawn. Topographic maps in the scale of 1/25 000 and modified geologic map in the scale of 1/100 000 were also used. The general geologic, geomorphic evolution and pedogeomorphology of the study area was used from the previous studies (Atalay, 2017; Atalay et al., 2017, 2019b; Altunbas, 2018).

The samples of the soil and semiweathered parent materials of the experimental sites were taken to determine of texture, $\mathrm{pH}, \mathrm{CaCO}_{3}$, organic matter and CEC (Cation exchange capacity). Their determinations were made at the Soil Laboratory of Soil Science and Plant Nutriment of Agricultural Faculty, Akdeniz University. Texture of soil samples determined based on Bouyoucos hydrometer method Bouyoucos (1955) and organic material was made Walkley-Black (Black, 1965), $\mathrm{CaCO}_{3}$ determined Jackson (1967), Exchangeable Cations determined according to $1 \mathrm{~N}$ ammonium acetate method Kacar (1995), Cation Exchange Capacity (CEC) determined According to sodium acetate method USDA (1969) and Kacar (1995), respectively.

\section{Results}

\section{Geologic setting and the formation of parent materials}

Gölhisar Basin which is located in the southern part of Lake Subregion in the northwestern part of the Mediterranean geographical Region of Turkey contains Mesozoic submarine ultramafic volcanic rocks, Mesozoic limestone-marble, neogene sedimentary deposit mostly containing marl and Quaternary fluvio-limnic, alluvial and colluvial deposit (Figs. 1 and 2). The basement of the study area is mainly composed of ultramafic rocks especially peridotite-serpentine rocks or parent materials that formed with the eruption of lava erupted from the mid-oceanic ridge and spread on the bottom of the Tethys Ocean occupying the present-day Taurus Mountain belt during the Lower Mesozoic period. The deposited mud composed of carbonates and clay materials on the bottom of Tethys Ocean was converted into limestones with folding and uplifting tectonic movements occurred during the end of Mesozoic Era. Present-day Gölhisar Basin collapsed by the faulting movements was occupied by the Neogene Lake in which clayey and calcareous materials were deposited. Neogene (Pliocene) marly deposits containing marl, sandy clay, calcareous siltstone and sandstone, and clayey layers intercalations are widespread in the southern part of Gölhisar Basin. Thick colluvial and fluvio-limnic deposits are found on the edge of the highlands encircled the Gölhisar 
Basin (Altunbas, 2018; Atalay, 2017; Atalay et al., 2017, 2019a). Alluvions occur on the bottom land of Gölhisar Basin (Figs. 2 and 3).

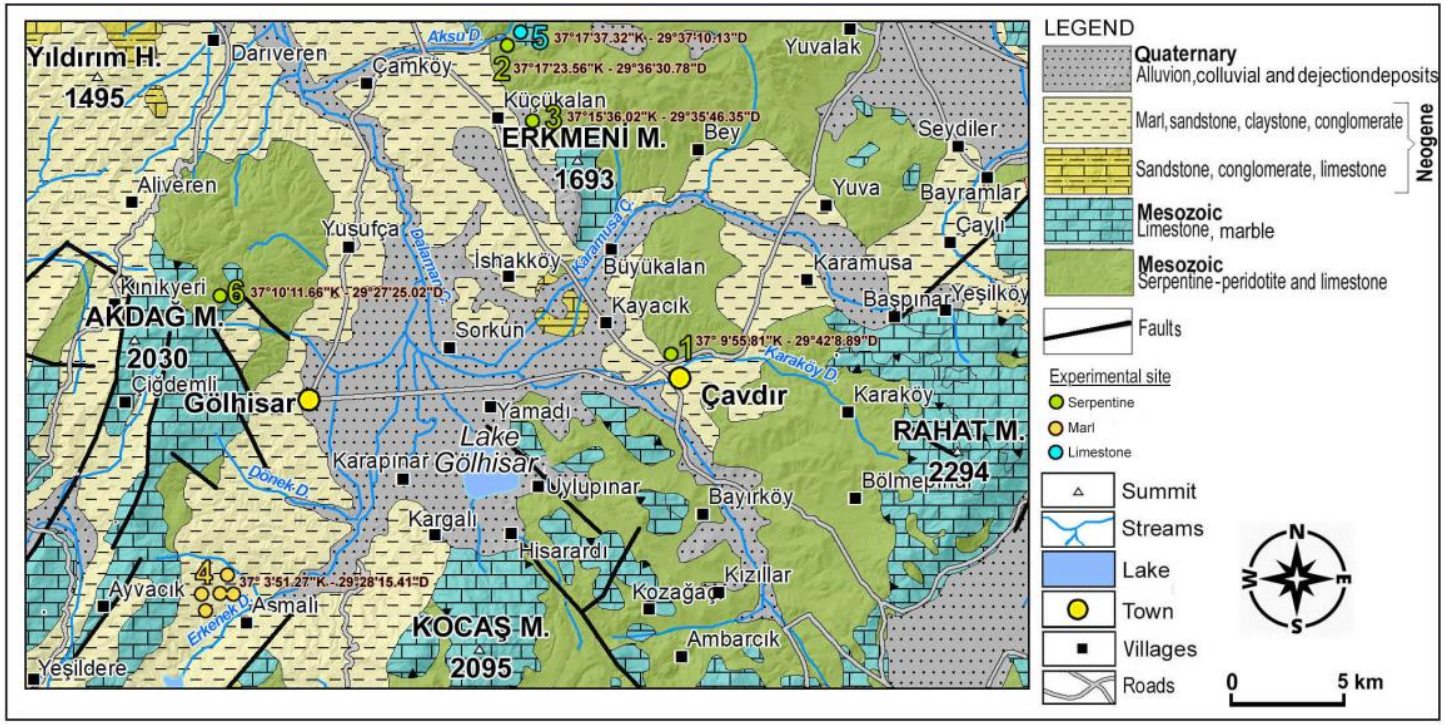

Figure 2. Geologic parent materials and experimental sites of the study area

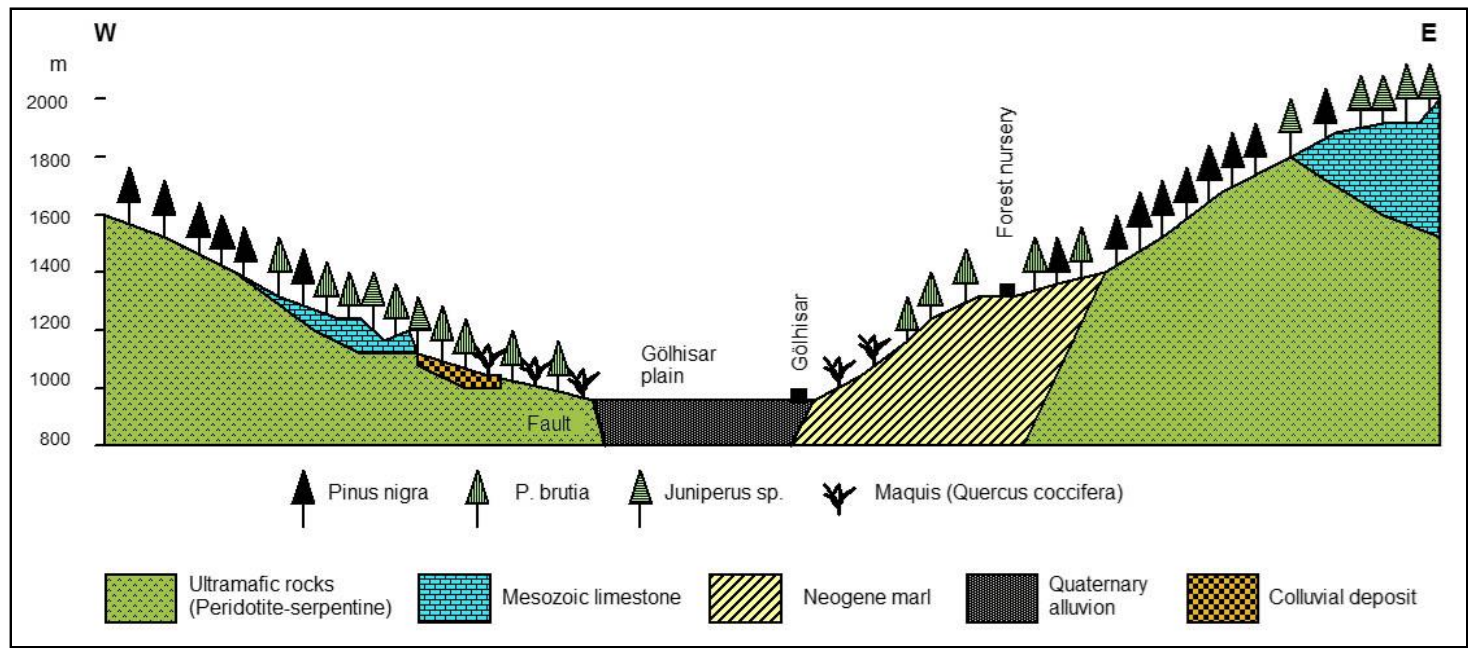

Figure 3. Geologic cross-section and forest trees distribution in the Gölhisar Basin

\section{Geomorphic-topographic setting}

Present-day topography of Gölhisar Basin was formed by the vertical tectonic movements occurred during the Neogene and Early Quaternary periods (Atalay et al., 2017). Main topographic-geomorphologic units and their formations are shortly explained below:

\section{Mountainous areas}

These areas encircling high mountainous areas of the basin were formed by the vertical faulting movements; the relative altitude between the collapsed Gölhisar Basin 
and its encircling highlands is more than $1000 \mathrm{~m}$. Thus, the highlands have been deeply dissected by the streams flowing into the basin. The slope inclination on fault scarps is over $80 \%$ especially on the mountain slopes facing Gölhisar town in the west of study area.

\section{Gully landforms}

Neogene Lake occupying the Gölhisar Basin was captured by the Dalaman River flowing in to Mediterranean Sea. Thus, emerging the Neogene Lake deposits have been also incised by the streams that established on the neogene deposit surface. Gully landform resembling bedland topography has been formed. The erosion on the marly deposits is commonly seen on the steep slopes of the valley in the southern part of the basin.

\section{Colluvial deposits}

Thick colluvial deposits that formed as the result of accumulation of the eroded materials derived from the upland areas are common on the edge of the mountainous areas. There is some close relationship between the topographic-geomorphological units and the growth rate of the trees in the study area, in general.

\section{Physical geography setting}

\section{Climate}

The climate of the study area is the transitional climate, characterized with a somewhat mild and rainy winters, a moderate hot and rainless summers, between the Mediterranean climate and continental climate of Central Anatolia according to climatic types of Turkey (Atalay, 2012). According to data obtained from the meteorological stations in the study area, mean annual temperature which is $12^{\circ} \mathrm{C}$ at the Gölhisar town decreases continually toward the highlands. The mean annual precipitation which is $\mathrm{c}$. $500 \mathrm{~mm}$ rises up to 700-800 $\mathrm{m}$ in the highlands. In the spreading areas of Calabrian pine (Pinus brutia) clusters the mean annual temperature is about $11-12{ }^{\circ} \mathrm{C}$, mean winter temperature is above freezing point, and mean annual precipitation changes between $300 \mathrm{~mm}$ and $600 \mathrm{~mm}$. In the Pinus nigra occurrence areas, mean annual temperature is nearly $8-9^{\circ} \mathrm{C}$ and mean annual precipitation is over $500 \mathrm{~mm}$.

\section{Soil}

In the study area, solum horizon is rarely seen due to the active erosion occurring in the sloping area. Most of soils belong to intrazonal soils reflecting the physical and chemical properties of parent materials in the study area (Atalay et al., 2019b). Indeed, lithosol/entisol containing serpentine particles is common at the all serpentine experimental sites. Clayey and calcareous soil is common on the steep slopes of marl deposit. Only thin A horizon of Rendoll subordo of Mollisol ordo or Rendzic Leptosol with clayey loam in texture and alkaline reaction occurs on the flat land of marl deposit. Red Mediterranean soil/Luvisol which is clayey in texture is found along the cracks of limestone at experimental site 5. Colluvial soil containing sandy and gravelly materials is common on the lower edge of hilly area as is found at experimental site 3. Plant nutriment capacity and texture of the soil/parent material depends on the weathering stage of parent materials, in general. 


\section{Vegetation}

Two main forest belts are found in the study area: Pinus brutia and Pinus nigra. The ecological properties of these forests in Mediterranean climatic region of Turkey and the study area are summarized below.

In Turkey, native occurrences areas of Calabrian pine (Pinus brutia Ten.) forests beginning seashore climb up to $1500 \mathrm{~m}$ on the south facing slopes of Taurus Mountains and cover the lower forest belt of the Mediterranean climatic region of Turkey. Mean annual temperature ranges from 12 to $18^{\circ} \mathrm{C}$ and mean January temperature is continually over $0{ }^{\circ} \mathrm{C}$. Mean yearly precipitation changes 400 and $2400 \mathrm{~mm}$ most of which fall during the winter season in the optimum growing areas of Calabrian pine forests that are very resistant against drought. It grows all parent materials. The highest productive areas were established summer rainy area and on flysch parent material composed of alternation of sandy, silty, clayey limestone layers in Adana Province (Atalay et al., 1998).

In the study area Calabrian pine (Pinus brutia) forest belt generally lies between 1000 and $1200 \mathrm{~m}$ and its vertical distribution considerable changes depending on aspect factors (Fig. 3). Indeed, the upper limit of the Calabrian pine climb up to $1500 \mathrm{~m}$ on the south facing slopes of mountains. Maquis vegetation composed of mainly Quercus coccifera which is the lowerstory vegetation of Calabrian pine forest is widespread where Calabrian pine forests have been destroyed.

In Turkey, native occurrence areas of Anatolian Pinus nigra subsp. pallasiana (Lamb.) Holmboe forests are found between the subhumid-cold climate and subhumidsemiarid continental climate of Turkey and their optimum growing areas cover inland part of the Northern Anatolian Region and oro-Mediterranean forest belt of Taurus Mountains. P. nigra forests commence at an elevation of $1000 \mathrm{~m}$ in the western inland part of the Northern Anatolia and climb up to $2400 \mathrm{~m}$ in the Kahramanmaras Province in the eastern part of Mediterranean Region. In the optimum growing areas the mean annual temperature is about $8{ }^{\circ} \mathrm{C}$, January temperature below the freezing point. The mean annual precipitation is over $600 \mathrm{~mm}$. Good site index of P. nigra forests appear backward region of western Black Sea Region, inland part of West Anatolia and ororegions of Aegean and Mediterranean Mountains (Atalay and Efe, 2010; Atalay, 2014).

In the study area, Anatolian black pine (Pinus nigra) forests begin on the upper level of the Calabrian forest belt mostly in the southern highland of the study area and climb up to $2000 \mathrm{~m}$. Some of Pinus nigra native occurrence areas are replaced by poor juniper communities composed of Juniperus oxycedrus, J. foetidissima and J. excelsa in places where P. nigra forests have been degenerated and destroyed (Fig. 3).

\section{Growth rate of trees at the experimental sites}

Experimental sites were selected to determine the growth rate of Calabrian pine (Pinus brutia) and Anatolian black pine P. nigra on the different parent materials in the Gölhisar Basin. Four experimental sites were selected on the serpentine which is a product of hydrous alternation of ultramafic rocks mostly peridotite in the bottom of ocean covers a large area in the study area (Figs. 2 and 3).

\section{The growth of Calabrian pine (Pinus brutia Ten.) experimental sites}

To reveal the growth rate of the Calabrian pine (Pinus brutia) two experimental sites were selected on the serpentine, one site on the colluvial deposit, and one site on the 
marl deposit; totally four sites belong to the Calabrian pine cluster (Fig. 2). General description sites and the measurement of age, height and diameter of Pinus brutia at the experimental sites are introduced below.

\section{Experimental site 1}

Located near the highway between Burdur-Gölhisar.

General description of the site: Experimental site is located near the Gölhisar-Burdur road, $10 \mathrm{~km}$ NE of Gölhisar, at an elevation of $1100 \mathrm{~m}, 37^{\circ} 9^{\prime} 55.81^{\prime \prime} \mathrm{N}-29^{\circ} 42^{\prime} 8.89^{\prime \prime} \mathrm{E}$. Undulating topography is dominant; serpentine is exposed in most part of the area due to the intense erosion. The height and diameter of Pinus brutia trees changes frequently depending on weathering degree of the serpentine; the highest height of P. brutia is found on the bottom of valley due to the collection of water and weathered serpentine; while, $P$. brutia trees which are in chaparral appearance are found on the exposed unweathered serpentine (Table 1; Fig. 4). Shirking aspect of this site it to show great changes on the height, diameter and age of Pinus brutia trees depending on different weathering stage of serpentine.

Table 1. The height, diameter and age of Pinus brutia on serpentine experimental site at an

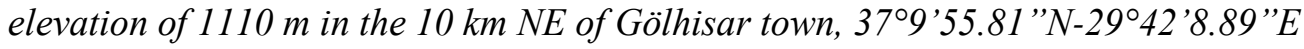

\begin{tabular}{c|c|c|c|c|}
$\begin{array}{c}\text { Weathering degree } \\
\text { of serpentine }\end{array}$ & Location of trees & $\begin{array}{c}\text { Height } \\
(\mathbf{m})\end{array}$ & $\begin{array}{c}\text { Diameter } \\
(\mathbf{c m})\end{array}$ & $\begin{array}{c}\text { Age } \\
(\text { year })\end{array}$ \\
\hline Good weathered & 1. Bottom of small valley & 14 & 38 & 45 \\
\hline Exposed serpentine & 2. The upper part of hill slope & 1.2 & 4 & 30 \\
\hline Semi weathered & 3. Top of the hill & 3.5 & 37 & 16 \\
\hline Weathered & 4. Top of hill & 3.2 & 14 & 37 \\
\hline Weathered & 5. Top of hill & 8 & 26 & 36 \\
\hline Semi weathered & 6. Top of hill & 4 & 26 & 36 \\
\hline
\end{tabular}

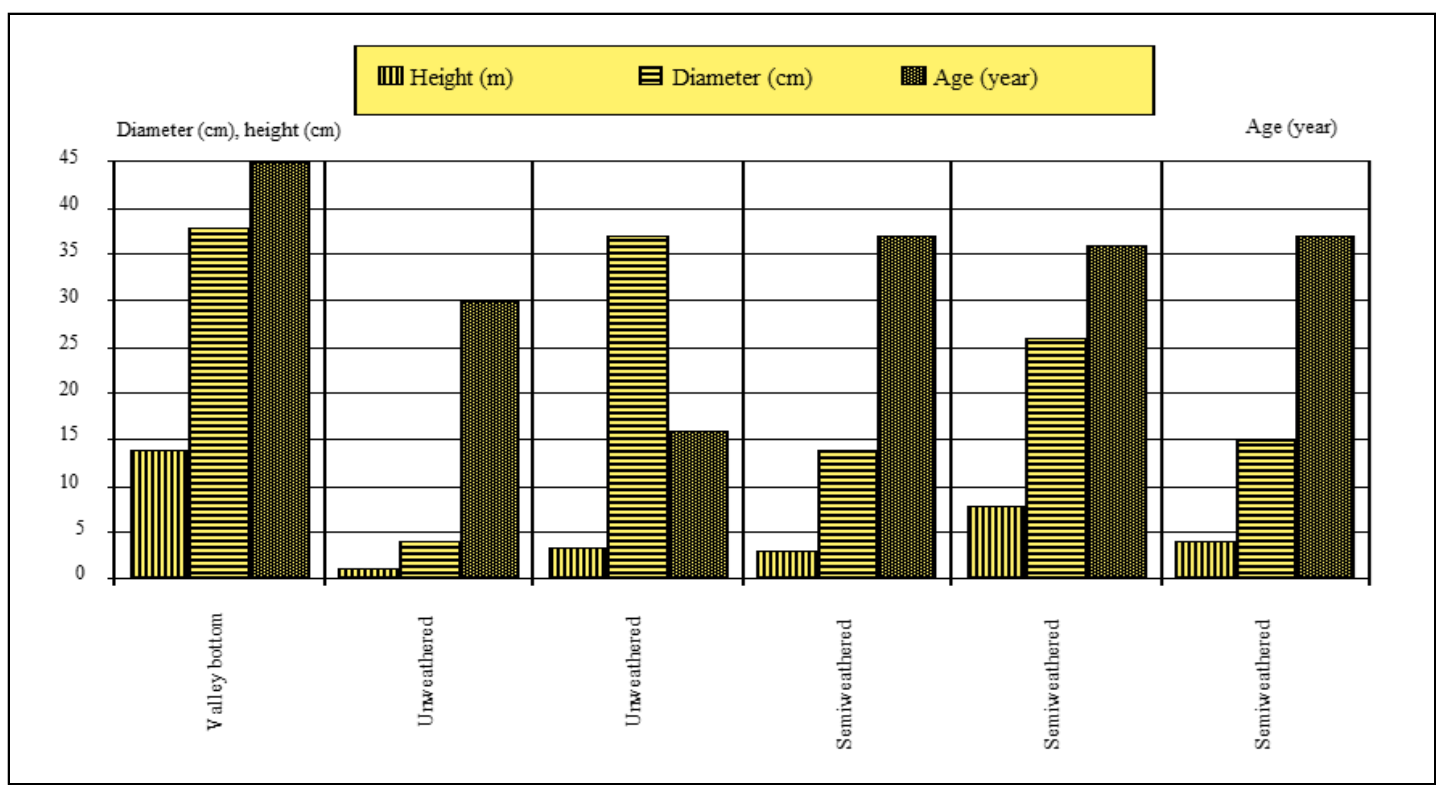

Figure 4. The graph illustrating the relationships among height, diameter and age of Pinus brutia at the experimental site 1 


\section{Experimental site 2}

Located on the western aspect of the valley in the c. $30 \mathrm{~km}$ north of Gölhisar, $37^{\circ} 17^{\prime} 23.56^{\prime \prime} \mathrm{N}-29^{\circ} 36^{\prime} 30.78^{\prime \prime} \mathrm{E}$.

General description of the site: Serpentine parent material is common. The weathering degree changes frequently depending of the slope inclination and erosion process. Semi weathered serpentine is widespread on the slightly inclined surface, but unweathered serpentine is exposed on steep slopes of valley. The dissected topography is common; slightly surfaces are found upper parts of the hills.

In this site great differences in the growth of Pinus brutia are seen to have depended on weathering of the serpentine. Indeed, the lowest growth rate was established on the active erosion place of steep slopes of valley on which unweathered serpentine was outcropped. There no great differences among the height of $P$. brutia on the slightly inclination area (Table 2; Fig. 5).

Table 2. The height, diameter and age of Pinus brutia on weathered serpentine experimental site at an elevation of $1100 \mathrm{~m}$ near road in $25 \mathrm{~km} N N E$ of Gölhisar, 37\%17'23.56" $N$ $29^{\circ} 36^{\prime} 30.78^{\prime \prime} E$

\begin{tabular}{|c|c|c|c|c|}
$\begin{array}{c}\text { Weathering degree } \\
\text { of serpentine }\end{array}$ & Location of tree & Height (m) & Diameter (cm) & Age (year) \\
$\begin{array}{c}\text { Weathered } \\
\text { serpentine }\end{array}$ & $\begin{array}{c}\text { The slope inclination } \\
\text { low }\end{array}$ & 16 & 34 & 85 \\
\hline $\begin{array}{c}\text { Weathered } \\
\text { serpentine }\end{array}$ & $\begin{array}{c}\text { The slope inclination } \\
\text { low }\end{array}$ & 21 & 42 & 98 \\
\hline $\begin{array}{c}\text { Low weathered } \\
\text { serpentine }\end{array}$ & $\begin{array}{c}\text { Inside of valley, } \\
\text { active erosion }\end{array}$ & 6 & 9 & 50 \\
\hline
\end{tabular}

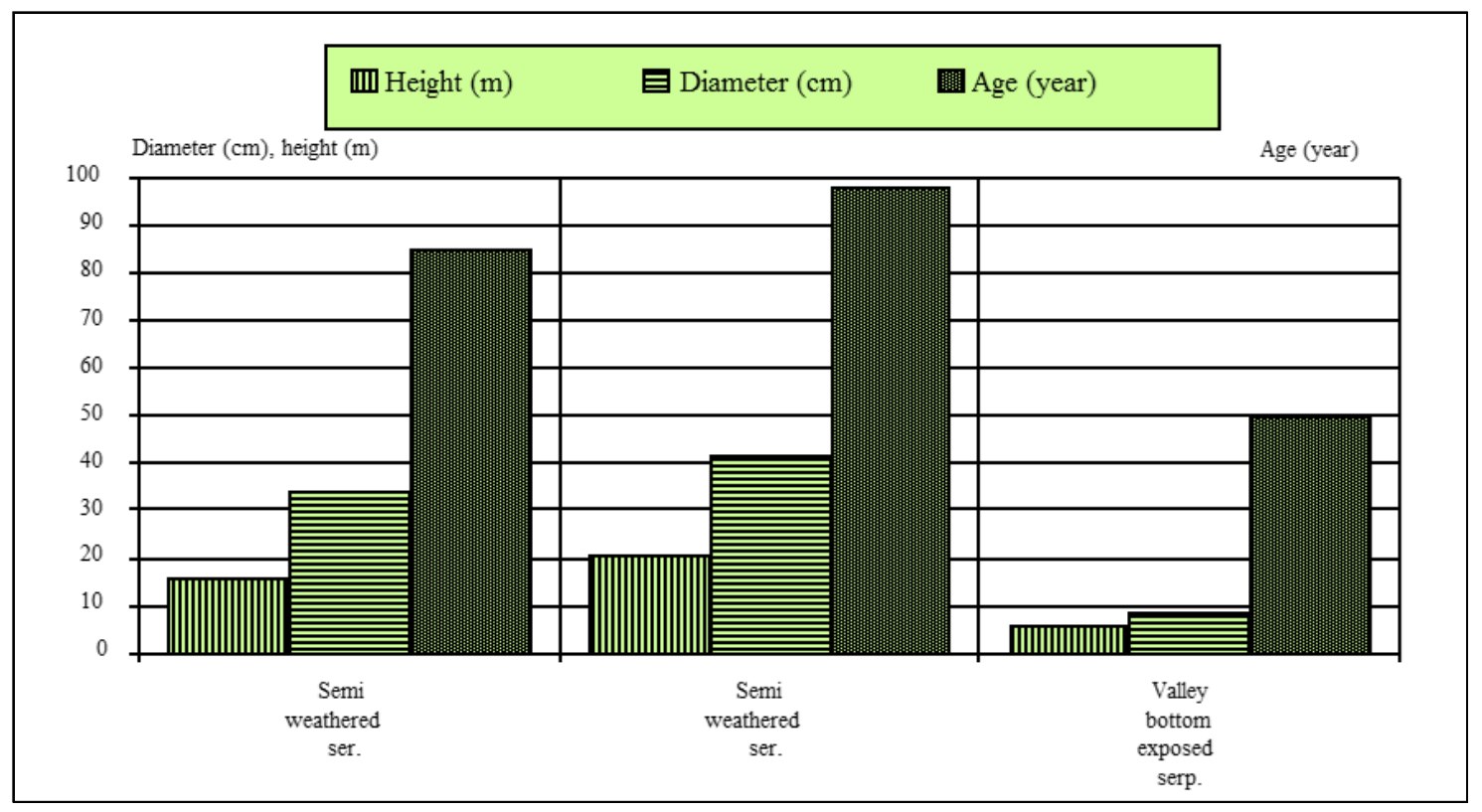

Figure 5. The graph showing the relationships among height, diameter and age of Pinus brutia at the experimental site 2 on serpentine 


\section{Experimental site 3}

Located on the colluvial deposit in the Gölova Forest Directory, near forest fire observation tower, at an elevation of $1150 \mathrm{~m}, 37^{\circ} 15^{\prime} 36.02^{\prime \prime} \mathrm{N}-29^{\circ} 35^{\prime} 46.35^{\prime \prime} \mathrm{E}$.

General description of the site: Topographically this site is found on slightly inclined area lying on the edge of hilly area. The colluvial deposit has been formed with the accumulation of the small gravels, sands and silts transported by the running water derived from the serpentine area. The reddish colour of the colluvial deposit clearly reflects a good oxidation process.

Thick colluvial deposit creates a good habitat for the growth of Pinus brutia. Because both horizontal and taproot development of root structure clearly show the existence of good ecological conditions on colluvial deposit. For this reason, there is no great difference among the height of trees in terms of height, diameter and age (Table 3; Fig. 6). The productive P. brutia trees are only found on the colluvial deposit when compared to other sites.

Table 3. Calabrian pine cluster on the colluvial gravelly deposit in Gölova forest directory of Gölhisar, $37^{\circ} 15^{\prime} 36.02$ 'N-29³5'46.35 ' $\mathrm{E}$

\begin{tabular}{c|c|c|c|c} 
Parent material & Topography & $\begin{array}{c}\text { Height } \\
(\mathbf{m})\end{array}$ & $\begin{array}{c}\text { Diameter } \\
(\mathbf{c m})\end{array}$ & $\begin{array}{c}\text { Age } \\
(\mathbf{y e a r})\end{array}$ \\
$\begin{array}{c}\text { Very thick gravelly, } \\
\text { sandy colluvial } \\
\text { deposit }\end{array}$ & $\begin{array}{c}\text { Slightly inclined } \\
\text { surface of colluvial } \\
\text { deposit }\end{array}$ & 12.5 & 32 & 57 \\
\hline Same & Same & 16 & 39 & 53 \\
\hline Same & Same & 17 & 40 & 58 \\
\hline
\end{tabular}

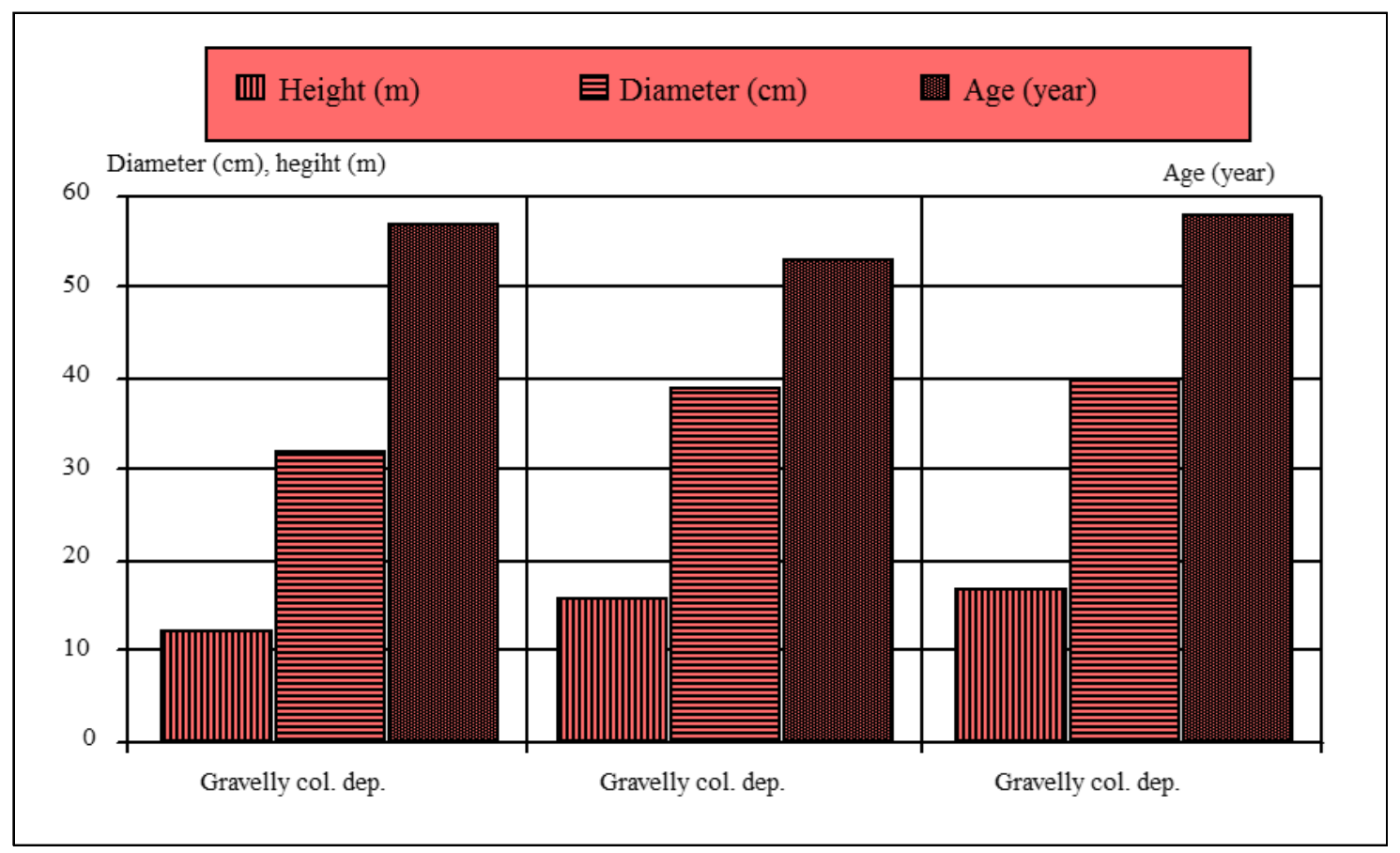

Figure 6. The graph showing the relationships among height, diameter and age of Pinus brutia on the colluvial deposit 


\section{Experimental site 4}

Located on the neogene marl deposit in the eastern part of the Gölhisar town at an elevation of $1100 \mathrm{~m}, 37^{\circ} 3^{\prime} 51.27^{\prime} \mathrm{N}, 2^{\circ} 28^{\prime} 15.41^{\prime \prime} \mathrm{E}$.

General description of site: Parent material is composed of marl deposits; it contains both horizontal and inclined calcareous sandstone, siltstone layers and gravelly lenses belonging to fluvial deposit. Marl deposit has been dissected by the tributaries of the main stream flowing into Gölhisar Plain. Small flatlands are seen on the horizontal layer among the upper parts of valleys. The debris flows occur on the steep slopes of valley. Entisol is common on the sloping areas; thin A horizon with rich organic content belonging to rendzina (Rendoll, Rendzic leptosol) is only seen on the flat land. P. brutia clusters occur everywhere of the area. But productive $P$. brutia is found on the soft marly deposit and inclined layers. A somewhat productive $P$. brutia trees appear on the marl horizontal layers with soft and crack structure supporting the taproot development, while compact marl creates a poor habitat for the growth of Pinus brutia. Besides the high sun radiation somewhat prevents the productivity of Pinus nigra on the slopes facing-south due to summer aridity. The growth rate of the Calabrian pine on the marl deposit is generally good as compared with the serpentine parent materials (Table 4; Fig. 7).

\section{The growth of Anatolian black pine (Pinus nigra subsp. pallasiana) experimental sites}

Anatolian black pine ( $P$. nigra) forests appearing upper boundary of the Calabrian pine (P. brutia) belt are found only small cluster in the $\mathrm{N}$ of Gölhisar and mountainous areas rising $2000 \mathrm{~m}$ of elevation in the southern part of the Gölhisar town. To reveal the growth rate of the Anatolian black pine on the limestone and serpentine two experimental sites were selected. General description sites and the measurement results of these experimental sites are introduced below.

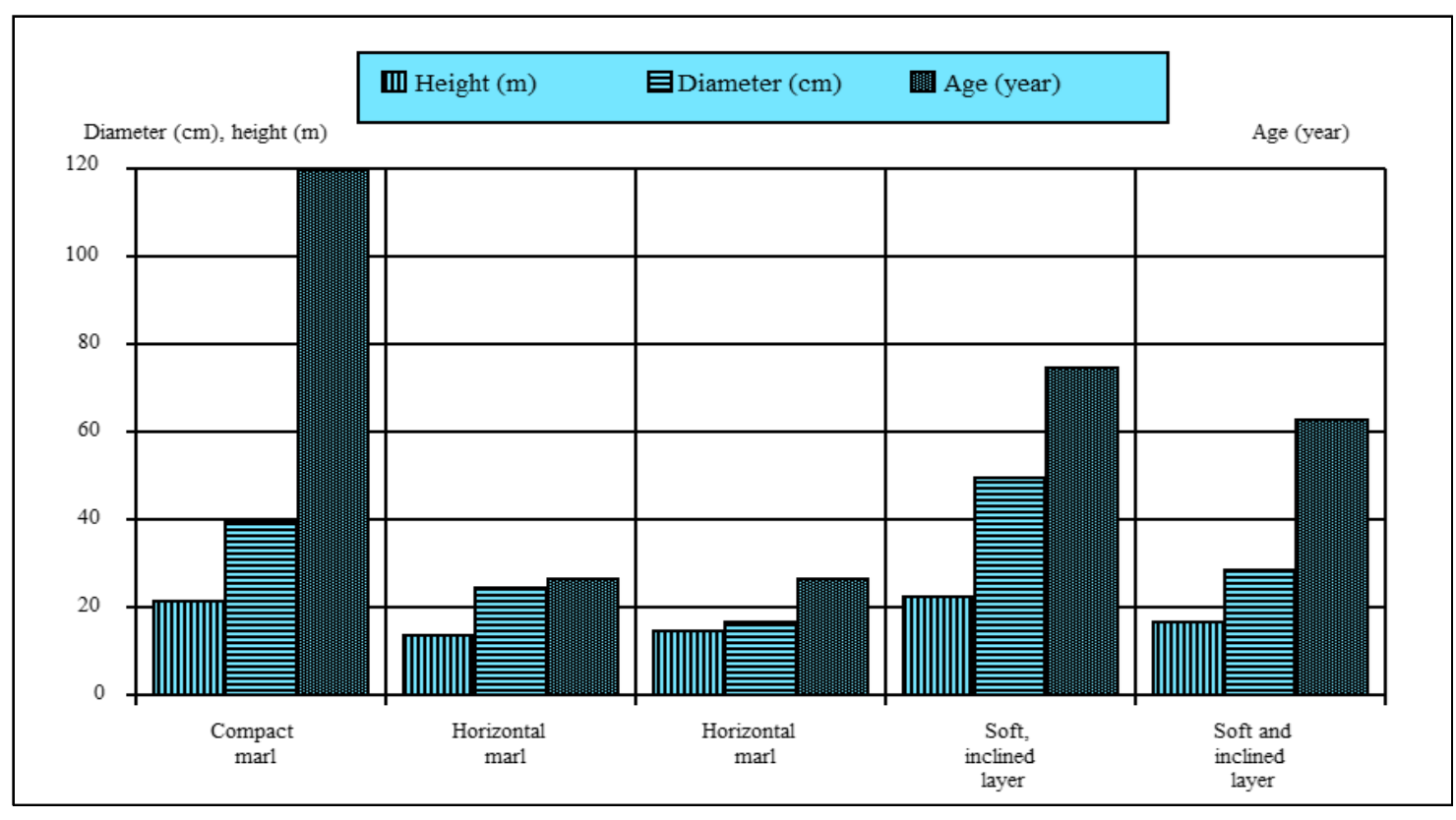

Figure 7. The graph showing relationships among height, diameter and age of Pinus brutia at the experimental site 4 on the marl deposit 
Table 4. Calabrian pine growing on the neogene marl deposit in the north of Gölhisar town

\begin{tabular}{|c|c|c|c|c|}
$\begin{array}{c}\text { Properties of } \\
\text { neogene deposits }\end{array}$ & Location & Height (m) & Diameter (cm) & Age (year) \\
\hline $\begin{array}{c}\text { Horizontal hard } \\
\text { layers }\end{array}$ & Almost flat land near road & 21.5 & 40 & 120 \\
\hline $\begin{array}{c}\text { Horizontal layers } \\
\text { Horizontal marl } \\
\text { layer }\end{array}$ & $\begin{array}{c}\text { Flat and radiation intensity } \\
\text { high }\end{array}$ & 14 & 25 & 27 \\
\hline $\begin{array}{c}\text { Soft and low radiation } \\
\text { intensity }\end{array}$ & 15 & 17 & 27 \\
\hline $\begin{array}{c}\text { marly layer } \\
\text { Soft and inclined } \\
\text { marly layer }\end{array}$ & $\begin{array}{c}\text { Upper part of the hill near } \\
\text { Gölhisar road }\end{array}$ & 23 & 50 & 75 \\
\hline
\end{tabular}

\section{Experimental site 5}

Located near the highway between Burdur-Gölhisar, at an elevation of $1200 \mathrm{~m}$, $37^{\circ} 17^{\prime} 37.32^{\prime \prime} \mathrm{N}-29^{\circ} 37^{\prime} 10.13 ’ \mathrm{E}$.

General description of site: Located in the $30 \mathrm{~km} \mathrm{NNW}$ of Gölhisar town. Cracked and crystallized limestone is common on the serpentine. The slope inclination is very low. Most of the Pinus nigra trees have been destroyed to obtain timber; thick litter cover appears under the of Pinus nigra cluster on the limestone. There is no surface erosion due to the rainfall easily infiltrates along the limestone cracks. There are no notably differences among $P$. nigra trees in terms of the height, diameter and age, in general (Table 5; Fig. 8). Cracked limestones containing low content of clay create a suitable condition for the growth of P. nigra; because of the roots of $P$. nigra easily develop toward the deeper part along the cracks of limestone.

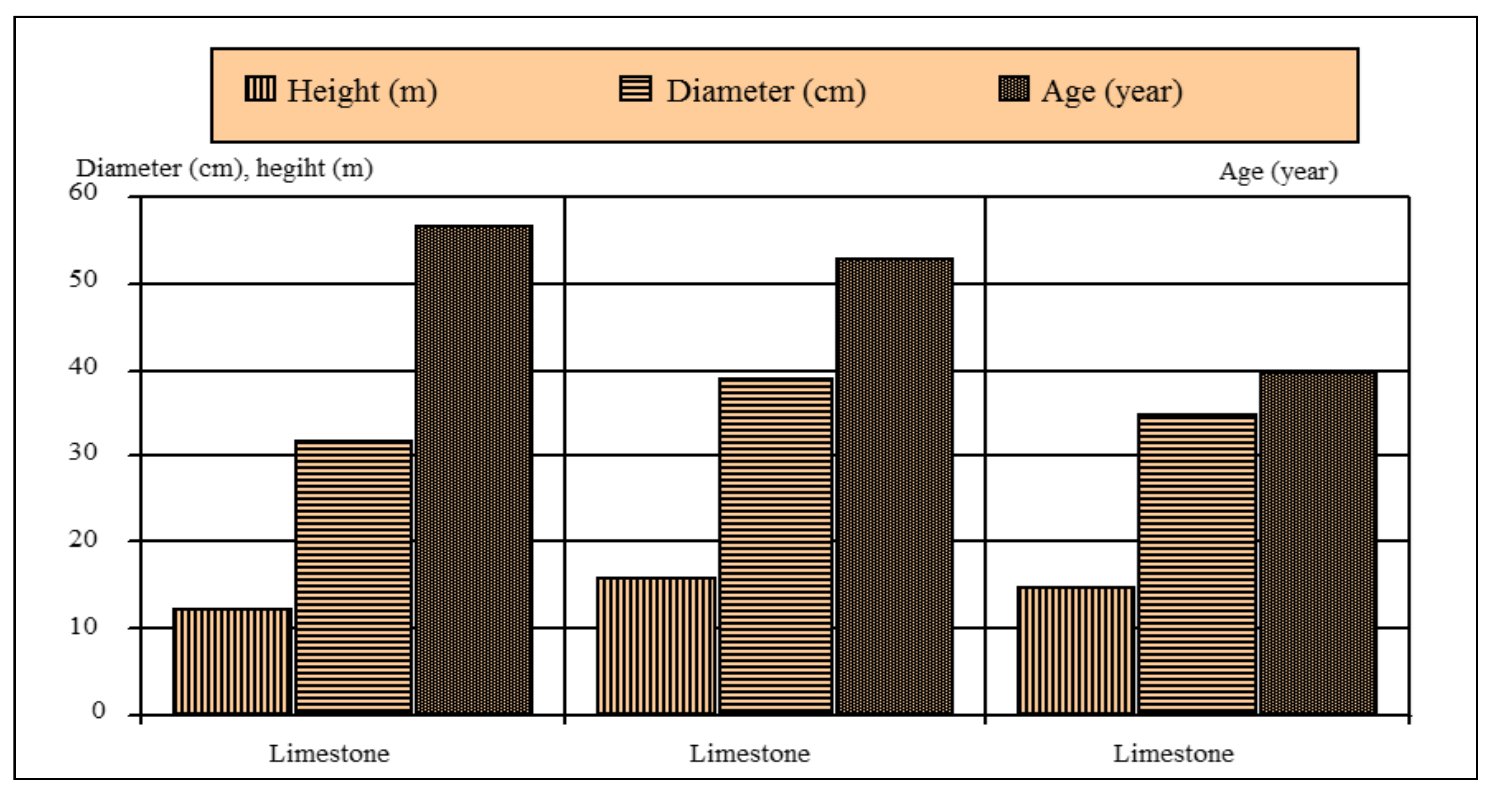

Figure 8. Relationships among height, diameter and age of Pinus brutia at the experimental site 5 on the limestone 
Table 5. Anatolian black pine cluster on the limestone, near the road, $25 \mathrm{~km} \mathrm{NNW}$ of Gölhisar, 37¹7'37.32”N, 29³7’10.13'”E

\begin{tabular}{c|c|c|c|c} 
Parent material & Topography & Height $(\mathbf{m})$ & Diameter (cm) & Age (year) \\
\hline Cracked Mesozoic limestone & Hill edge slightly inclination & 17 & 41 & 48 \\
\hline Cracked limestone & Limestone blocks & 14 & 30 & 38 \\
\hline Cracked limestone & Limestone blocks & 15 & 35 & 40
\end{tabular}

\section{Experimental site 6}

Güdük Hill locality on Ak Mountain, far from $30 \mathrm{~km}$ in the west of Gölhisar town, $1600-1700$ m, 37¹0'11.66”N-29²7'25.02”'E.

Description of the site: Güdüktepe locality is found at an elevation of 1600-1700 m on the east facing slopes of the Ak Mountain in the western part of Gölhisar town (Fig. 1 and 2). Parent material is composed of cracked and unweathered serpentine. Inclination of the slope is more than 60\%, and its elevation is about $1600-1700 \mathrm{~m}$. Güdük Hill is one of the main spreading areas of $P$. nigra forests. Here lithosol/entisol is common due to intense erosion. Lithosol and over grazing activity prevents considerably the regeneration of $P$. nigra. That is why; $P$. nigra seedlings that are rarely seen indicate presence of low native regeneration.

In this experimental site, $P$. nigra grows within the cracks and the partly weathered vertical zone of serpentine. The highest $P$. nigra is found on the cracked serpentine; because the roots of the $P$. nigra easily follow deeply along the cracks of serpentine. Shrinking aspect of this area, weathered serpentine particles have been transported by the runoff due to high inclination of the slope. It can be said that the site index of the $P$. nigra is in poor quality on the exposed serpentine. The growth rate of P. nigra is tend to increase from the steep slope to the upper part of the hill and wide bottom of valley, in general. However, there is no direct relationship between the diameter and height of $P$. nigra trees, but considerable differences of Pinus nigra age imply the weathering process occurring along the cracks of serpentine, especially in the root zone (Table 6; Fig. 9).

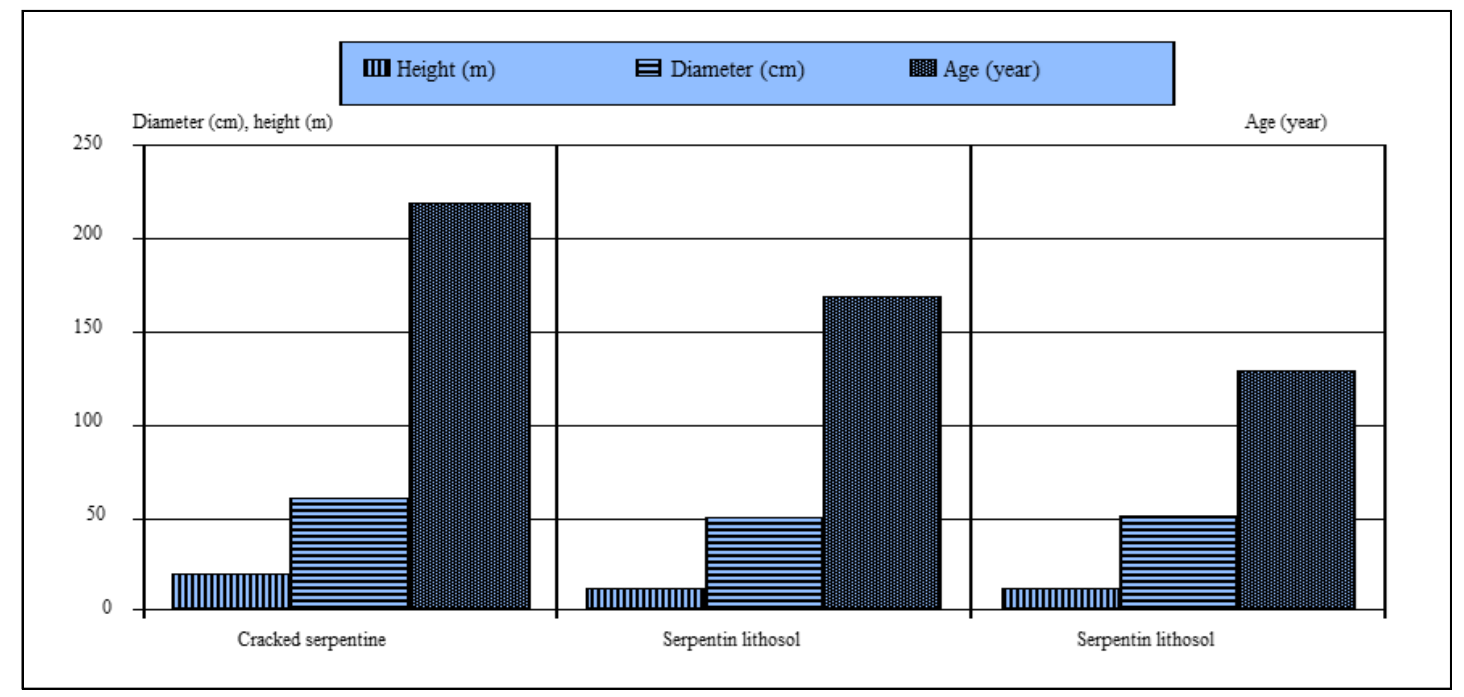

Figure 9. Relationships among height, diameter and age of Pinus nigra at the experimental site 6 on the serpentine in the Göktepe locality, Ak Mountain 
Table 6. Relationships among height, diameter and age of Pinus nigra at the experimental site 6 on the serpentine

\begin{tabular}{c|c|c|c|c} 
Parent material & Topography & Height $(\mathbf{m})$ & Diameter (cm) & Age (year) \\
\hline Cracked serpentine rock & Slightly inclined surface & 21 & 62 & 220 \\
\hline Lithosol & Near top of hill & 13 & 51 & 170 \\
\hline Lithosol & Lower slope of valley & 13 & 52 & 130 \\
\hline
\end{tabular}

\section{Relationship between growth rate of vegetation and physical and chemical properties of parent materials}

According to field observations and the data of laboratory analysis of soils and parent materials in the study area there is close relationship between the growth rate of vegetation and weathering degree and/or stage of serpentine. As is seen experimental site 1, the highest height Calabrian pine tree is found on good and deeply weathered serpentine with CEC (Cation exchange capacity) $33 \mathrm{cmol}_{\mathrm{c}} \mathrm{kg}^{-1}$, this figure is c. $13 \mathrm{cmol}_{\mathrm{c}}$ $\mathrm{kg}^{-1}$ at the site of the lowest height of Calabrian pine (Table 7). Poor stand forest in appearance of dwarf trees and shrubs are common on the low weathered and exposed serpentine which is in green colour. One of these areas notably preventing factor to grow of herbaceous vegetation is found at the Taşpınar locality in the SW of Lake Ak. Here CEC of low weathered and exposed serpentine is about $2 \mathrm{cmol}_{\mathrm{c}} \mathrm{kg}^{-1}$. In this place other preventing factor is the presence of thin sandy soil with very low field capacity and dissecting with rills that are formed with the transportation of sandy particles by runoff (Table 8). The presence of a few Pinus brutia trees are not related the low CEC on the sandy soil because the growth of P. brutia depends on the weathering process in the root zone. In other words, the release of the plant nutriments on the serpentine surface determine only the growth of seedlings and herbaceous vegetation but the growth rate and/or productivity of trees is mainly related to the weathering degree of the root zone (Table 7). Organic material of all sites is less than $1 \%$.

Table 7. Some physical and chemical properties of serpentine at experimental site 1

\begin{tabular}{c|c|c|c|c|c|c|c|c|c|c}
$\begin{array}{c}\text { Parent } \\
\text { material } \\
\text { properties }\end{array}$ & $\begin{array}{c}\text { Sand } \\
(\%)\end{array}$ & $\begin{array}{c}\text { Clay } \\
(\%)\end{array}$ & $\begin{array}{c}\text { Silt } \\
(\%)\end{array}$ & $\begin{array}{c}\text { Texture } \\
\mathbf{c l a s s}\end{array}$ & $\begin{array}{c}\mathbf{C a C O}_{3} \\
(\%)\end{array}$ & $\begin{array}{c}\mathbf{K} \\
\left(\mathbf{c m o l}_{\mathbf{~}} \mathbf{~ k g}^{-1}\right)\end{array}$ & $\begin{array}{c}\mathbf{C a} \\
\left(\mathbf{c m o l}_{\mathbf{~}} \mathbf{~ k g}^{-1}\right)\end{array}$ & $\begin{array}{c}\mathbf{M g} \\
\left(\mathbf{c m o l}_{\mathbf{~}} \mathbf{~ g g}^{-1}\right)\end{array}$ & $\begin{array}{c}\mathbf{~ N a} \\
\left(\mathbf{c m o l}_{\mathbf{~}} \mathbf{~ k g}^{-1}\right)\end{array}$ & $\begin{array}{c}\mathbf{C E C} \\
\left(\mathbf{c m o l}_{\mathbf{~}} \mathbf{~ k g}^{-1}\right)\end{array}$ \\
$\begin{array}{c}\text { Upper part of } \\
\text { weathered } \\
\text { serpentine }\end{array}$ & 59 & 21 & 20 & $\mathrm{SCL}$ & 13.7 & 1 & 51 & 4.3 & 0.26 & 24.3 \\
$\begin{array}{c}\text { Lower part of } \\
\text { weathered } \\
\text { serpentine }\end{array}$ & 79 & 7 & 14 & $\mathrm{LS}$ & 5.1 & 0.2 & 60 & 12 & 0.5 & 33 \\
\hline $\begin{array}{c}\text { Less weathered } \\
\text { serpentine }\end{array}$ & 71 & 13 & 16 & $\mathrm{SL}$ & 6.7 & 0.1 & 39.4 & 3.4 & 12 & 12.9 \\
\hline $\begin{array}{c}\text { Sand of } \\
\text { serpentine }\end{array}$ & 73 & 7 & 20 & $\mathrm{SL}$ & 1.5 & 0.04 & 3.2 & 3.4 & 12 & 20 \\
\hline
\end{tabular}

On the other hand, release of the $\mathrm{CaCO}_{3}$, clay contents and cations mainly of $\mathrm{Ca}^{++}$ and $\mathrm{Mg}^{++}$are higher on the deeply weathered serpentine than on low weathered serpentine. This is responsible for the increase of CEC in the weathered serpentine (Tables 8-10; Fig. 10). 
Table 8. Some physical and chemical analysis of exposed serpentine at Tasspinar locality, $37^{\circ} 38^{\prime} 38.13^{\prime \prime} N-29^{\circ} 45^{\prime} 33.46^{\prime \prime} E$ in the SW of Lake Ak locality, north of Gölhisar Basin

\begin{tabular}{c|c|c|c|c|c|c|c|c|c|c}
$\begin{array}{c}\text { Parent } \\
\text { material } \\
\text { properties }\end{array}$ & $\begin{array}{c}\text { Sand } \\
(\%)\end{array}$ & $\begin{array}{c}\text { Clay } \\
(\%)\end{array}$ & $\begin{array}{c}\text { Silt } \\
(\%)\end{array}$ & $\begin{array}{c}\text { Texture } \\
\text { class }\end{array}$ & $\begin{array}{c}\mathbf{C a C O}_{3} \\
(\%)\end{array}$ & $\begin{array}{c}\mathbf{K} \\
\left(\mathbf{c m o l}_{\mathbf{~}} \mathbf{~ k g}^{-1}\right)\end{array}$ & $\begin{array}{c}\mathbf{C a} \\
\left(\mathbf{c m o l}_{\mathbf{c}} \mathbf{~ k g}^{-1}\right)\end{array}$ & $\begin{array}{c}\mathbf{M g} \\
\left(\mathbf{c m o l}_{\mathbf{~}} \mathbf{~ k g}^{-1}\right)\end{array}$ & $\begin{array}{c}\mathbf{~ N a} \\
\left(\mathbf{c m o l}_{\mathbf{c}} \mathbf{~ k g}^{-1}\right)\end{array}$ & $\begin{array}{c}\mathbf{C E C} \\
\left(\mathbf{c m o l}_{\mathbf{c}} \mathbf{~ k g}^{-1}\right)\end{array}$ \\
$\begin{array}{c}\text { Exposed soft } \\
\text { serp. with rill }\end{array}$ & 67 & 6 & 27 & $\mathrm{SL}$ & 14.8 & 0.1 & 10 & 9.7 & 0.1 & 1.8 \\
$\begin{array}{c}\text { Low } \\
\text { weathered } \\
\text { bare serp. }\end{array}$ & 67 & 6 & 27 & $\mathrm{SL}$ & 2.9 & 0.1 & 10 & 9.7 & 0.11 & 2.0 \\
$\begin{array}{c}\text { Low } \\
\text { weathered } \\
\text { bare serp. }\end{array}$ & 71 & 13 & 16 & $\mathrm{SL}$ & 6.7 & 0.1 & 39.4 & 3.4 & 12 & 12.9 \\
\hline $\begin{array}{c}\text { Partly } \\
\text { weathered } \\
\text { serp. with } \\
\text { herb }\end{array}$ & 65 & 9 & 26 & $\mathrm{SL}$ & 2 & 0.8 & 21 & 5.7 & 0.14 & 14.5 \\
\hline
\end{tabular}

Table 9. Some physical and chemical data of serpentine melange area at $2 \mathrm{~km}$ northwest of Yeşilova town, 37³1'13.34”N-2946’39.32”'E, Burdur province

\begin{tabular}{|c|c|c|c|c|c|c|c|c|c|c|}
\hline $\begin{array}{c}\text { Parent } \\
\text { material } \\
\text { properties }\end{array}$ & $\begin{array}{c}\text { Sand } \\
(\%)\end{array}$ & $\begin{array}{l}\text { Clay } \\
(\%)\end{array}$ & $\begin{array}{l}\text { Silt } \\
(\%)\end{array}$ & $\begin{array}{l}\text { Texture } \\
\text { class }\end{array}$ & $\begin{array}{c}\mathrm{CaCO}_{3} \\
(\%)\end{array}$ & $\underset{\left(\mathrm{cmol}_{\mathrm{c}} \mathrm{kg}^{-1}\right)}{\mathbf{K}}$ & $\underset{\left(\mathrm{cmol}_{\mathrm{c}} \mathbf{k g}^{-1}\right)}{\mathrm{Ca}}$ & $\underset{\left(\mathrm{cmol}_{\mathrm{c}} \mathrm{kg}^{-1}\right)}{\mathrm{Mg}}$ & $\begin{array}{c}\mathrm{Na} \\
\left(\mathrm{cmol}_{\mathrm{c}} \mathrm{kg}^{-1}\right)\end{array}$ & $\begin{array}{c}\text { CEC } \\
\left(\mathrm{cmol}_{\mathrm{c}} \mathrm{kg}^{-1}\right)\end{array}$ \\
\hline $\begin{array}{c}\text { Deeply } \\
\text { weathered } \\
\text { serpentine }\end{array}$ & 46 & 25 & 29 & L & 33 & 0.3 & 36.3 & 13.5 & 0.12 & 34.4 \\
\hline $\begin{array}{c}\text { Deeply } \\
\text { weathered } \\
\text { reddish } \\
\text { serpentine }\end{array}$ & 37 & 29 & 24 & CL & 23 & 0.4 & 37.5 & 14.7 & 0.13 & 43.8 \\
\hline $\begin{array}{c}\text { Less } \\
\text { weathered } \\
\text { serpentine }\end{array}$ & 79 & 9 & 12 & LS & 33.7 & 0.05 & 20.8 & 2.8 & 0.03 & 13.8 \\
\hline
\end{tabular}

Table 10. Some physical and chemical analysis of marl deposits in the south of Gölhisar town

\begin{tabular}{c|c|c|c|c|c|c|c|c|c|c}
$\begin{array}{c}\text { Parent } \\
\text { material } \\
\text { properties }\end{array}$ & $\begin{array}{c}\text { Sand } \\
(\%)\end{array}$ & $\begin{array}{c}\text { Clay } \\
(\%)\end{array}$ & $\begin{array}{c}\text { Silt } \\
(\%)\end{array}$ & $\begin{array}{c}\text { Texture } \\
\text { class }\end{array}$ & $\begin{array}{c}\mathbf{C a C O}_{\mathbf{3}} \\
(\%)\end{array}$ & $\begin{array}{c}\mathbf{K} \\
\left(\mathbf{c m o l}_{\mathbf{c}} \mathbf{~ k g}^{-1}\right)\end{array}$ & $\begin{array}{c}\mathbf{C a} \\
\left(\mathbf{c m o l}_{\mathbf{c}} \mathbf{~ k g}^{-1}\right)\end{array}$ & $\begin{array}{c}\mathbf{M g} \\
\left(\mathbf{c m o l}_{\mathbf{~}} \mathbf{~ k g}^{-1}\right)\end{array}$ & $\begin{array}{c}\mathbf{~ N a} \\
\left(\mathbf{c m o l}_{\mathbf{c}} \mathbf{~ k g}^{-1}\right)\end{array}$ & $\begin{array}{c}\mathbf{C E C} \\
\left(\mathbf{c m o l}_{\mathbf{c}} \mathbf{~ k g}^{-1}\right)\end{array}$ \\
$\begin{array}{c}\text { Marl deposit } \\
\text { in S of } \\
\text { Gölhisar }\end{array}$ & 17 & 27 & 56 & $\mathrm{SiL}$ & 53.7 & 0.8 & 49.6 & 15.3 & 0.29 & 23.8 \\
\hline Marl deposit & 11 & 47 & 42 & $\mathrm{SiC}$ & 48 & 1.3 & 40.7 & 18.7 & 0.28 & 33.7 \\
\hline $\begin{array}{c}\text { Compact marl } \\
\text { deposit }\end{array}$ & 21 & 23 & 56 & $\mathrm{SiC}$ & 40.5 & 0.4 & 34.4 & 8.7 & 0.15 & 10.48 \\
\hline
\end{tabular}

The weathering process in melange area that is composed of the mixture limestone and serpentine frequently changes. In such area, the amounts of CEC of the serpentine depend on the weathering and oxidation process. For instance, in the melange area at the $2 \mathrm{~km}$ northwest of the Gölhisar town CEC changes between 12.8 and $43.8 \mathrm{cmol}_{\mathrm{c}} \mathrm{kg}^{-1}$ (Table 9). The fertile agricultural fields are common on the flat land of melange areas of the study area in general. On the other hand, the cracks of serpentine contribute to develop deeply of root system, and chemical and physical weathering processes occurring along the root 
and crack zones contribute tend to increase the releases of the abundant plant nutriments. This situation produces a good habitat for the growth of trees. In fact, cracked serpentine and deeply developed root system support to increase of the biomass productivity of all trees.

CEC of the soil developed on the serpentine changing between 35 and $50 \mathrm{cmol}_{\mathrm{c}} \mathrm{kg}^{-1}$ forms fertile agricultural lands in the Gölhisar Basin. Soft marl deposit containing sand particles is generally responsible for the growth of forest due to deeply root development of trees. While compact marl deposit and horizontal compact layers mostly prevent to form good stand of forest because taproot development of trees is very hard and CEC is less than the soft marl deposit (Table 10).

\section{General relationships among the height, diameter and age of the trees}

There are great differences among the height, diameter and ages of the trees at most of the experimental sites. The highest differences are seen in P. brutia sparse cluster on the different weathered serpentine at experimental site 1 . Here, the ranges of the height $1.2 \mathrm{~m}$ to $8 \mathrm{~m}$, diameter 4 to $37 \mathrm{~cm}$, and age 16 to 45 years. This is mainly related to the weathering stages of serpentine. There is no considerable difference among the $P$. brutia trees on serpentine colluvial deposit at experimental site 3 and $P$. nigra trees at experimental site 5 on the limestone. These last two sites can be regarded as productive forest cluster (Fig. 10).

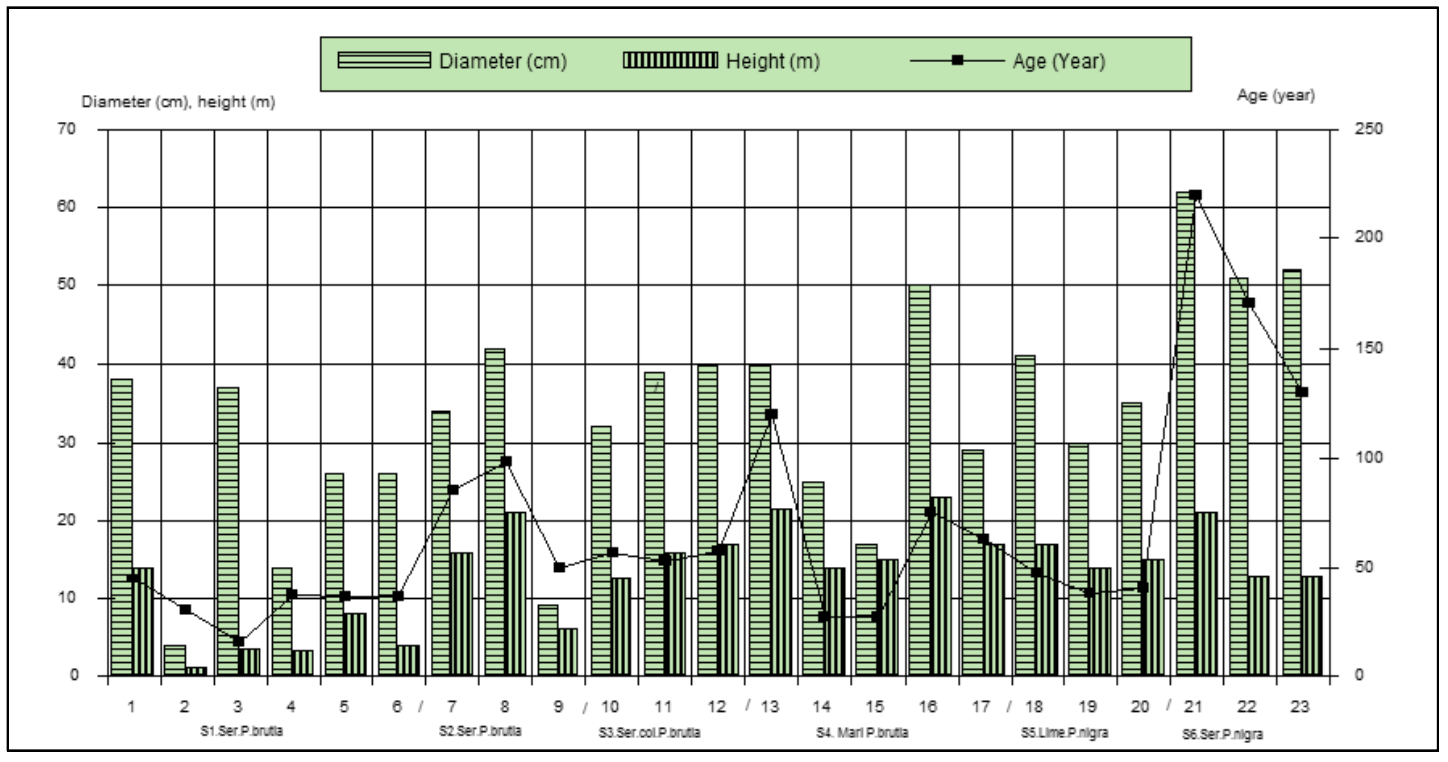

Figure 10. The graph showing relationships among the age, diameter and height of the individual trees at the experimental sites reveals the importance of the tree growth notably depending on parent materials. "/" indicates between the boundary of experimental sites. (Abbreviations: S1, 2, 3... experimental sites. Ser. serpentine. Ser. col. Serpentine colluvial deposit)

\section{General relationship between height and age}

Relationship between height and age is one of the indicators of the productivity in uniform ecological environment. In the productive habitats there are very little differences between the height and diameter of trees (Saatcioglu, 1976). Very little 
differences between height and age are found among the $P$. nigra trees growing on the limestone at experimental site 5 and among the $P$. brutia trees growing on the serpentine colluvial deposit at site 3 . Here parent materials are in uniform properties. The increase of the differences among the trees indicates clearly the existence of different parent materials and their weathering stages. The existence of great difference between the height and age may relate to the inclination of layer and compactness of marl deposit at the experimental site 5 (Fig. 11).

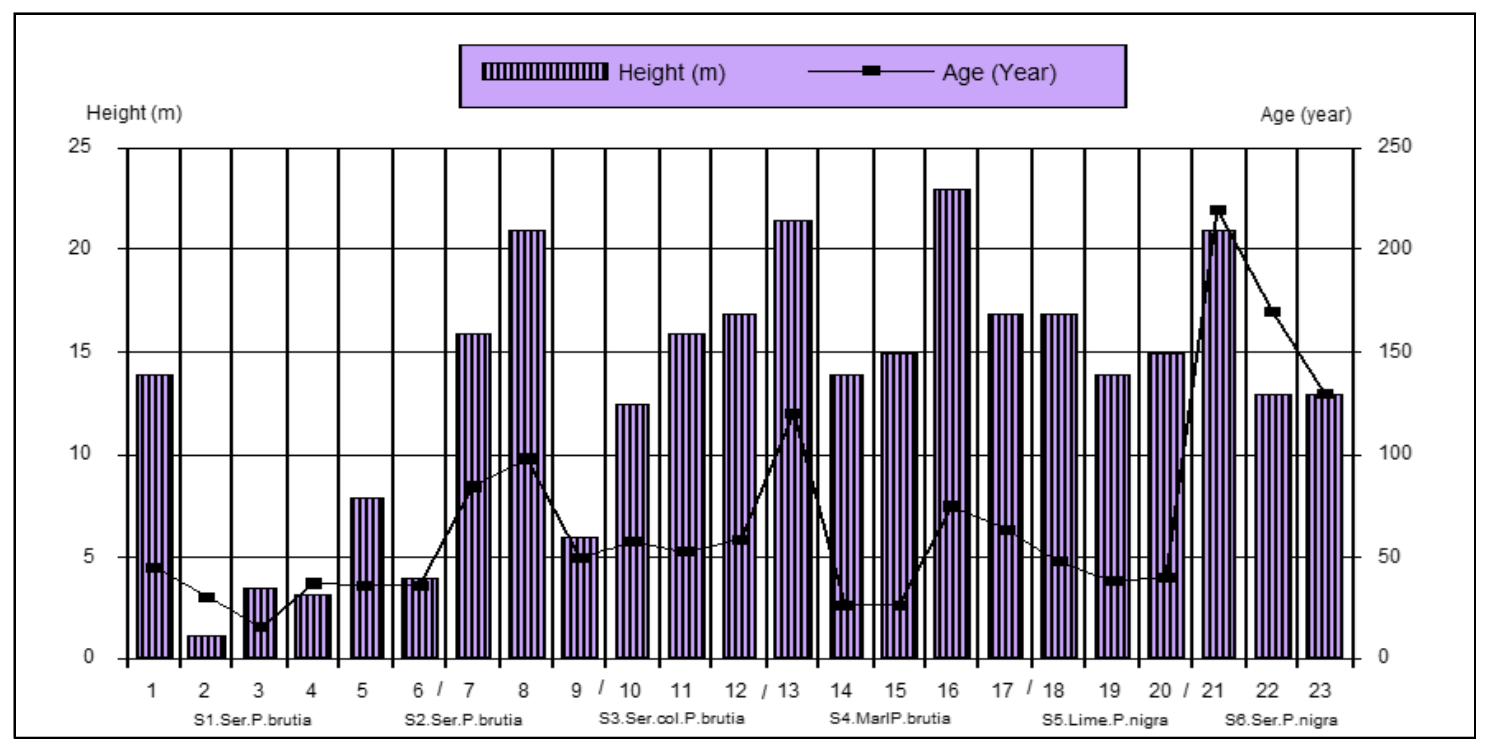

Figure 11. The relationship between height and age of trees in the experimental sites

\section{The general relationship between age and diameter}

As a general rule, the thickness of diameter continually increases toward the end of felling cycle (rotation, length) of trees and diameter thickness is the best indicator of the annual increment of trees. There is irregular relationship between age and thickness of diameter of most of trees in the study area. Indeed, the great changes are found between the age and diameter at experimental sites 1,2, 4 and 6; this is related to the different weathering process of the parent materials, while the reasonable relationship between diameter and age is found on the serpentine colluvial deposit at site 3 and on the limestone at site 5 (Fig. 12).

\section{Available water effects on the tree growth}

Available water capacity of the soil and parent material is generally low due to high inclination surface and sandy and sandy loam texture of soil. Most of the atmospheric water flow as runoff/overland flow on the serpentine and marl deposit occurring on the inclined surface. Here available water of trees depends on the amount of infiltration capacity of water through the cracks and collection of water in the root zone. In the karstic/limestone area almost all atmospheric water easily infiltrates via the cracks of limestone; thus, tree roots take available water from the soil that is developed along the cracks. For this reason, the tree growth rate is higher on the karstic land occurring in the study area, especially at site 5. Meanwhile, that tree productivity is high on colluvial deposit as is the site 3 is related to the accumulation of the water. Individual tree growth also depends on the available water 
content in the root zone. For example, at the experimental site 1 the lowest growth rate of Pinus brutia tree is found on the steep slopes, while highest growth rate of Pinus brutia is found on the bottom of the small valley due to water collection (Table 1; Fig. 4). Field capacity is very low on the sandy material on the serpentine occurring sloping area especially in the vicinity of Taşpınar village. Here the occurrence of the rill erosion and absence of herbaceous vegetation is mainly related to the transportation of mostly sandy particles by runoff and low field capacity of sandy soil.

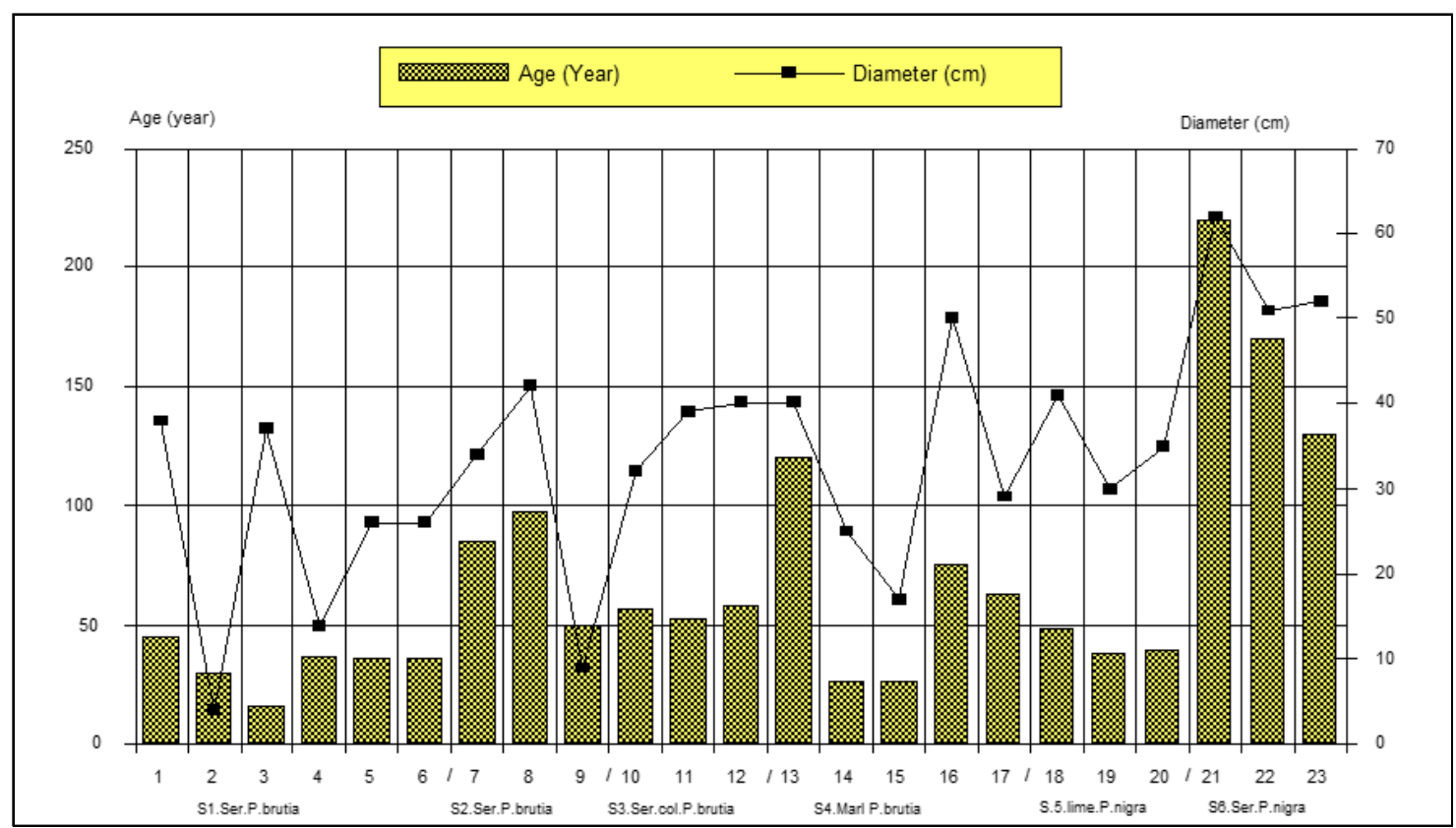

Figure 12. The relationships between age and diameter at the experimental sites

\section{Human impact on the growth of trees}

The settlement history of Gölhisar basin back to Neolithic period dated at least 7000 year BP (Roberts, 1990; Atalay, 1992). The vegetation especially forest destruction was probably commenced during the Roman period. At that time the famous historical city Kibyra (UNECO heritage city) was located on the crossroads of Phrygian, Carian, Lycian and Pisidian cultures and of commercial routes running east-west and north-south directions on the lower slope of the Ak Mountain in $1 \mathrm{~km}$ south of present-day Gölhisar town. Up to present time, most of the forests have been destroyed and degenerate to obtain timber and agricultural land. With the degeneration of the forest, soil and parent material erosion has been started on the sloping area. Thus, parent materials have been outcropped in the various parts of Gölhisar depression. As mentioned before, outcropped parent materials have been led to decrease the growth rate of the trees at most of the experimental sites. It can be said that forest destruction is one of the main reasons of tree growth on parent materials exposed on the degenerated forest area of Gölhisar Basin.

\section{Statistical evaluation}

According to statistical evaluation depending on the height, diameter and age of the trees, one-way ANOVA test for Pinus brutia, no significant correlation was found in the data range $(\mathrm{P}<0.05)$. 
As a result of the independent T-test for Pinus nigra, a significant correlation was found on the age and diameter of the trees $(\mathrm{P}<0.05)$ of different parent material. A difference in the tree heights of different parent materials $(\mathrm{P}<0.05)$ was not found.

\section{Discussion}

Vegetation growth and its productivity depend on not only climatic conditions but also physical and chemical properties of the parent materials. In the flat and slightly undulating areas of same climatic region parent material effects on the tree growth is very little. In these areas site index of forest is found in same category. But growth rate and/or productivity of forest changes considerably depending on the weathering process of the parent materials. In Turkey, the site index of forests shows great difference in terms of timber quality and biomass productivity. For example, the low site index Calabrian pine occurs on the siliceous parent material in north of Foca in the north of Aegean Sea shore, trachyte in south of the Lake Tortum, low weathered serpentine in western coastal belt of Antalya Gulf, Datça peninsula in the south-western part of Anatolia and horizontal marl deposits (Çukur, 1999; Çukur and Atalay, 2004; Atalay, 2014; Atalay and Efe, 2014).

On the other hand, the parent material effects on the tree growth are one of the significant procedures in the silvicultural application and reforestation and afforestation activities. For example, the seedlings to be planted on compact marl deposit have been subjected to dry during one and three year period, because the vertical development of seedlings' roots has been prevented by the horizontal layered and compact marl deposit (Atalay et al., 2014). To make successful reforestation and afforestation marl deposit should be deeply ploughed to plant the seedlings. Unweathered and low weathered serpentine forming hard surface also mostly prevents the natural regeneration. As a matter of fact, the cedar (Cedrus libani) plantation to be carried out on the marl deposit and serpentine is not appropriate application since the ecology of the cedar is taken into consideration in the Burdur-Gölhisar Basin. First time, the CEC of the serpentine depending on weathering process and marl deposit on the growth of trees are explained in our study. Stone pine (Pinus pinea) reforestation to be carried out on the serpentine is inappropriate application, because this pine only grows on the sand dunes and sandy soil developed on the granite and gneiss under the Mediterranean climatic conditions (Atalay, 2014). In the forest management planning and the classification of forest stand index, the importance of parent material effects have been not sufficiently used in Turkey.

The importance of serpentine, marl and limestone forming lithobiome is detailed explained on the tree growth and the response to the land degradation process. Indeed, in the study area, the exposed unweathered serpentine and marl deposit on the forest destroyed sloping areas can be regarded as vulnerable areas for the formation of land degradation.

To establish the productivity and/or site index and to select the species of trees in the reforestation and afforestation activities it is necessary to classify the natural environment according to lithobiomes and pedobiomes (Bailey, 1995a, b, 1998; Atalay, 2014). These biomes form a distinct habitat on which flora and fauna is different than that other biomes. To classify of given natural environment as biomes can be regarded the one of fundamental principles of sustainable planning of the plant especially forest growth, site index and productivity. On the other hand, these classifications will 
contribute the selection of tree species in the reforestation and afforestation activities and silvicultural applications. However, similar studies relating to forestry have not been conducted except for "Ecoregions of Turkey (Atalay, 2014).

\section{Conclusion}

The parent material effects on the growth rate and/or productivity of trees in the sloping areas is one of leading issues in the determination of forest products, silvicultural applications and reforestation activities. In the study first time we analyzed the importance of the serpentine, limestone, marl and colluvial deposits on the growth of Pinus brutia and Pinus nigra trees. In the further studies the lithobiomes and pedobiomes should be used in the assessment of the natural environment and tree growth, and similar studies should be carried out. These studies are necessary to sustainable planning on the forest production and maintain the natural equilibrium.

Acknowledgements. We would like to offer our gratitude to Forest Engineer Oktay Demirci for measurements of the height, diameter and age of the trees and Emrah Ramazanoglu for statistical evaluation of trees. We would like special thanks to Bekir Karacabey, General Director of Forest of the General Forest Directory, Ministry of Agriculture and Forest, Kenan Akduman, Isparta Regional Director of Forest and Celal Korkmaz Burdur Forest Operation Manager for their supports and helps the project named "Ecology, ecosystem and Rehabilitation of Marble Quarries in the Burdur-Gölhisar Basin", prepared by I. Atalay, S. Altunbas and M. Siler.

\section{REFERENCES}

[1] Altunbas, S. (2018): Pedogeomorphology of the Burdur-Gölhisar Basin, SW Anatolia, Turkey. - Fresenius Environmental Bul. 28(1-2): 139-149.

[2] Atalay, İ. (1987): Sedir (Cedrus libani A. Rich) General Ecological Properties of the Natural Occurrence Areas of Cedar (Cedrus libani A. Rich) and Regioning of Seed Transfer of Cedar in Turkey. - Publications of General Directorate of Forestry 663/61, Ankara.

[3] Atalay, İ. (1992): The Paleogeograhy of the Neareast (From Late Pleistocene to Early Holocene) and Human Impact. - Aegean University Press, Bornova, Izmir, Turkey.

[4] Atalay, İ. (1997): Red Mediterranean soils in some karstic regions of Taurus Mountains, Turkey. - Catena 28: 247-260.

[5] Atalay, İ. (2012): Applied Climatology. - Meta Press, İzmir.

[6] Atalay, İ. (2014): Ecoregions of Turkey $\left(2^{\text {nd }}\right.$ Ed.). - Meta Press, İzmir.

[7] Atalay, İ. (2016a): Applied Geomorphology (in Turkish). - Meta Press, İzmir.

[8] Atalay, İ. (2016b): Soil Formation, Classification and Geography (in Turkish). - Meta Press, İzmir.

[9] Atalay, İ. (2017): Geomophology of Turkey (in Turkish). - Meta Press, İzmir.

[10] Atalay, İ., Efe, R. (2010a): Structural and distributional evaluation of forest ecosystems in Turkey. - Journal of Environmental Biology 31: 61-70.

[11] Atalay, İ., Efe, R. (2010b): Ecology of the Anatolian Black Pine (Pinus nigra subsp. pallasiana (Lamb.) Holmboe) and Its Dividing into Regions In Terms Of Seed Transfer.

- Publications of Ministry of Environment and Forestry No. 424, Publications of Seed Breeding Research Directorate No. 37.

[12] Atalay, İ., Efe, R. (2014): The Factors Determining of Forest Productivity in the Western Part of Taurus Mountains (SW Anatolia). - In: Efe, R., Öztürk, M. (eds.) Tourism - 
Environment and Ecology in the Mediterranean Region II. Chap. 8. Cambridge Scholars Publishing, Cambridge, UK, pp. 111-128.

[13] Atalay, İ., Sezer, L. İ., Çukur, H. (1998): Kızılçam (Pinus brutia Ten.) Ecology of Red Pine (Pinus brutia Ten.) Forests and Their Dividing into Regions in Terms of Seed Transfer. - Publications of Forest Trees and Seed Breeding Research Directorate, No: 6.

[14] Atalay, İ., Adigüzel, H., Dal, N. (2017): Geomorphological evolution of the Gölhisar depression, SW Anatolia, Turkey. - In: Tonbul, S. Şengün, T., Siler, M., Canpolat, A. (eds.) Proceeding Book of the International Symposium on Geomorphology, 12-14 October 2017, pp. 137-145.

[15] Atalay, İ., Altunbas, S., Siler, M., Dal, N. (2019a): Ecology, Ecosystem and Rehabilitation of Marble Quarries in the Burdur-Gölhisar Basin, SW Anatolia. - General Directorate of Forestry, Ankara (in press).

[16] Atalay, İ., Altunbas, S., Siler, M. S. (2019b): The Importance of Marl Deposits on the Soil Formation, Land-Use and Land Degradation in Turkey. - In: Naml1, A. et al. (eds.) Proc. of $10^{\text {th }}$ International Soil Congress, Successful Transformation toward Land Degradation Neutrality: Future Perspective, Akça, pp. 82-89.

[17] Black, C. A. (1965): Soil-Plant Relationships. - John Wiley and Sons, Inc., New York.

[18] Bouyoucos, G. J. (1955): A reclamation of the hydrometer method for making mechanical analysis of the soils. - Agronomy Journal 4(9): 434.

[19] Bailey, R. G. (1995a): Description of the Ecoregions of the United States. - United States Department of Agriculture Forest Service, Pub No. 1391, Washington, DC.

[20] Bailey, R. G. (1995b): Ecosystem Geography. - Springer, New York.

[21] Bailey, R. G. (1998): Ecoregions. The Ecosystem Geography of the Oceans and Continents. - Springer, New York.

[22] Carter, S. P., Proctor, J., Slingsby, D. R. (1987): Soil and vegetation of the Keen of Hamar serpentine, Shetland. - Journal of Ecology 75: 21-42.

[23] Cerda, A. (1999): Parent material and vegetation affect soil erosion in Eastern Spain. Soil Science Soc. of America 63(2): 362-368.

[24] Cukur, H. (1999): Ecosystems of Aegean Region. - Unpublished Doctorate Thesis, Educational Sciences Institute, Dokuz Eylul University, Izmir.

[25] Cukur, H., Atalay, İ. (2004): The Effects of the Parent Material on the Natural Environment of Turkey. - Ielenicz, M., Popescu, N., Baltearu, D., Atalay, İ. (eds.) Environmental Change and Sustainable Development Proc. of Second Romanian-Turkish Workshop of Geography. Editura Universitara, Bucharest, pp. 145-154.

[26] Cunningham, W. P., Saigo, B. W. (1999): Environmental Science. - WCB, McGraw-Hill.

[27] Foth, H. D. (1990): Fundamentals of Soil Science. - John Wiley and Sons, New York.

[28] Going, B. M., Hillerislambers, J., Levine, J. M. (2009): Abiotic and biotic resistance to grass invasion in serpentine annual plant communities. - Oecologia 159(4): 839-847).

[29] Gregorich, E. G., Turchenek, L. W., Carter, M. R., Angers, D. A. (2001): Soil and Environmental Science Dictionary. - CRC Press, Boca Raton, FL.

[30] Jackson, M. C. (1967): Soil Chemical Analysis. - Prentice Hall of India Private Limited, New Delhi.

[31] Kacar, B. (1995): Chemical Analyses of Soil and Plant. III. Soil Analyses. - Ankara University, Agricultural Faculty, Ankara.

[32] Özdeniz, E., Özbey. B. G., Kurt, L and Bölükbaş1, A. (2017): Serpentine ecology and contributions to the serpentine flora of Turkey. - Journal of Soil Science and Plant Nutrition 5(1): 22-33).

[33] Oze, C., Skinner, C., Robert, W. S., Coleman, G. (2008): Growing up green on serpentine soils: Biogeochemistry of serpentine vegetation in the Central Coast Range of California. - Applied Geochemistry 23(12): 3391-3403. 
[34] Proctor, J., Woodell, R. J. (1975): The ecology of Serpentine soils. - Advances in Ecological Research 9: 255-366.

[35] Roberts, N. (1990): Human-Induced Landscape Change in the South and Southwest Turkey during the Late Holocene. - In: Bottema, S., Entjes-Nieborg, G., Van Zeist, W. (eds.) Man's role in the shaping of the East Mediterranean Landscape. A. A. Balkema, Rotterdam/Brookfield, pp. 53-68.

[36] Saatçioglu, F. (1976): Biological Fundamentals and Principles of Silviculture. - İstanbul Univ. Faculty of Forest Pub. 222, İstanbul.

[37] Smith, R. L., Smith, T. M. (2003): Elements of Ecology. $5^{\text {th }}$ Ed. - Benjamin Cumming, San Francisco.

[38] Tetik, M., Yeşilkaya, Y. (1997): Relationships Bedrock-Soil and Bonitet-Soil in the Pine Forest of Antalya Region. - Western Mediterranean Forestry Research Directorate, No 6.

[39] USDA (1969): Soil Taxonomy - A. Basic System of Soil Classification for Making and Interpreting Soil Surveys. Agriculture Handbook, No: 436. - Soil Con. Serv., Washington, DC. 